\title{
Incorporation of residues from the minero-metallurgical industry in the production of clay-lime brick
}

\author{
Welington L. Ferreira, Érica L. Reis*, Rosa M.F. Lima \\ Department of Mining Engineering, Federal University of Ouro Preto, Ouro Preto, MG, Brazil
}

\section{A R T I C L E I N F O}

\section{Article history:}

Received 10 December 2013

Received in revised form

19 August 2014

Accepted 5 September 2014

Available online 16 September 2014

\section{Keywords:}

Clay-lime bricks

$\mathrm{Fe}-\mathrm{Si}-\mathrm{Mn}$ slag

Soapstone powder

Pozzolanic materials

\begin{abstract}
A B S T R A C T
Industrial processes such as the extraction and processing of building and dimension stone and the manufacturing of ferroalloys generate large amounts of waste, which can cause environmental damage. Therefore, the development of new techniques for recycling and reusing industrial waste would be useful for minimizing the environmental impacts of these activities. This paper presents the incorporation of soapstone powder and $\mathrm{Fe}-\mathrm{Si}-\mathrm{Mn}$ slag in clay-lime brick as a partial substitution for agglomerate (lime) because these residues meet the standard specification for the chemical composition of a pozzolanic material. The results show that brick samples where $25 \%$ lime is substituted by waste residues achieved a compressive strength above $2.0 \mathrm{MPa}$, which is within the standard specification, after 28 days of curing (soapstone powder) or 60 days of curing (soapstone powder and $\mathrm{Fe}-\mathrm{Si}-\mathrm{Mn}$ slag). These materials were classified as class II, non-inert residues.
\end{abstract}

\section{Introduction}

The southeastern region of Brazil (the states of São Paulo, Minas Gerais, Rio de Janeiro and Espírito Santo) is the most developed region in the country and has intense mineral-metallurgical activity. Brazilian steel production totalled 35,162 Mt (Jesus, 2012) in 2011, and the state of Minas Gerais is responsible for $53.2 \%$ of all Brazilian mineral production (IBRAM, 2012).

The total recovery of dimension stone is very low. Gencel et al. (2012) reported that $20-30 \%$ of the marble block extracted in Turkey turns into dust during the cutting process. In Brazil, the total recovery of dimension stone in quartzite and soapstone quarries is approximately $30-40 \%$ per extracted volume (Rodrigues and Lima, 2012). It is common practice all over the world to dispose of the waste from dimension stone processing plants in landfills, which creates a high environmental impact.

In the steel industry, 0.7 to $1.7 \mathrm{t}$ of slag is produced for each tonne of steel (WSA, 2013). In Fe-Si-Mn alloys, 0.9 to $2.2 \mathrm{t}$ of slag is

\footnotetext{
* Corresponding author. Departamento de Engenharia de Minas, Universidade Federal de Ouro Preto, Campus Universitário, Morro do Cruzeiro, S/No., CEP.: 35400000, Ouro Preto, MG, Brazil. Tel.: +55 313559 1590; fax: +55 3135591593.

E-mail addresses: erica@demin.ufop.br, ericalreis@hotmail.com (É.L. Reis).
}

produced for each tonne of alloy (Olsen et al., 2007). For actual Brazilian steel production, 35,162 Mt (Jesus, 2012) of steel is produced along with 24,613.4 to 597,757.4 Mt of slag per year. In 2012, the $\mathrm{Fe}-\mathrm{Si}-\mathrm{Mn}$ alloy industry located in Ouro Preto, Minas Gerais produced $48,794.12$ t of slag. Part of the produced slag is normally returned to the steel process; however, the majority must be stored.

Recycling has the potential to reduce the amount of waste disposed of in landfills and to preserve natural resources. Construction materials such as brick and concrete that contain waste materials can support construction sustainability and contribute to the development of civil engineering by reusing industrial waste, minimizing the consumption of natural resources and producing more efficient materials (Pelisser et al., 2011; Gencel et al., 2012, 2013). All of the above mentioned factors are important when the Brazilian habitation deficit is taken into account (Nascimento, 2007).

Clay-lime bricks are easy to manufacture and through processes that do not include burning, which avoids the environmental impacts associated with burning manufacturing processes (Figueiredo, 2011). Among other advantages, lime soil bricks reduce the usage of bedding mortar and coatings due to the quality and final appearance of the bricks, which are markedly superior to their counterparts. These advantages stem from the dimensional regularity and facial flatness of lime soil bricks compared to conventional ones. For this reason, lime soil bricks can be easily used in 
masonry, requiring only waterproofing and a finishing cover (Marino and Boschi, 1998).

In this paper, slag from $\mathrm{Fe}-\mathrm{Si}-\mathrm{Mn}$ alloy and soapstone powder produced by the alloy industry and soapstone quarries in the Ouro Preto region of Minas Gerais, Brazil, were used as partial replacements of lime for brick manufacturing. Their pozzolanic characteristics and the possibility to decrease the final price of produced bricks were evaluated in order to assess the bricks as building materials, especially for the poorest economic class of the population.

\section{Materials and methods}

\subsection{Materials characterization}

The following characteristics of the raw materials used to produce brick mixtures were previously characterized: particle-size distribution, qualitative mineralogical composition, chemical composition, density and specific surface area.

Particle-size analysis was performed by wet sieving (Tyler series-3360 to $37 \mu \mathrm{m}$ ). X-ray diffraction (total powder method) was used to identify the main minerals in slag, clay and lime. For this purpose, a diffractometer with $\mathrm{Cu}$ tube (PanAnalytical model Empyrean) was used. Diffraction data were collected from $2^{\circ}$ to $72^{\circ}$. An ultrapycnometer (model 1200e, version 4.00) and BET (model 1200e) were used to determine the densities and specific surface areas of the raw materials, respectively. The run conditions of the ultrapycnometer were as follows: analysis temperature of $27.9^{\circ} \mathrm{C}$, target pressure of 19.0 psig, dry Helium gas, and a flow purge of 4 min (the final density was determined as the average of three determinations). The BET measurements were performed using a degasification time of $16 \mathrm{~h}$ at $200{ }^{\circ} \mathrm{C}$. The determination was performed in a $30 \mathrm{ml} / \mathrm{min}$ nitrogen flux at a temperature of $77.3 \mathrm{~K}$. The chemical compositions were analysed by inductively coupled plasma-optical emission spectroscopy (Spectro model Ciros/CCD). Loss on ignition was determined by gravity method. Clay Altteberg's limits were determined based on ABNT NBR 6459/84 and NBR $7180 / 84$ standards.

\subsection{Preparation of brick samples}

Raw bricks were produced using one part agglomerate with 10 parts of brick clay (fraction size $-4.8 \mathrm{~mm}$ in accordance with NBR 6457/86 standard). Clay-lime bricks (no added residue) and bricks with the addition of $25 \%, 50 \%$ and $75 \%$ slag from the manufacture of $\mathrm{Fe}-\mathrm{Si}-\mathrm{Mn}$ alloys or thin soapstone replacing part the lime. The amount of added water was determined based on the standard practice of the NBR 7182/86 standard, which specifies the optimum humidity. Table 1 presents the brick mixture generated from the raw materials.

Table 1

The brick mixture prepared from the raw materials.

\begin{tabular}{llllll}
\hline Sample & \multicolumn{2}{l}{ Agllomerate } & Clay $-4.8 \mathrm{~mm}$ & Humidity (\%) \\
\cline { 2 - 4 } & Lime & $\begin{array}{l}\text { Soapstone } \\
\text { powder }\end{array}$ & Fe-Si-Mn slag & \\
\hline RF & 1 & - & - & 10 & 22 \\
ST1 & 0.75 & 0.25 & - & 10 & 21 \\
ST2 & 0.50 & 0.50 & - & 10 & 20.5 \\
ST3 & 0.75 & 0.25 & - & 10 & 20.0 \\
SL1 & 0.75 & - & 0.25 & 10 & 21.0 \\
SL2 & 0.50 & - & 0.50 & 10 & 20.5 \\
SL3 & 0.25 & - & 0.75 & 10 & 20.0 \\
\hline
\end{tabular}

Obs.: $\mathrm{RF}$ - reference; $\mathrm{ST}$ - soapstone; $\mathrm{SL}$ - slag.
A hydraulic press (Nowak model PM 15 TON) was used to make the cylinder bricks, which were $5.00 \times 10.0 \mathrm{~cm}$ in size. Fig. 1 depicts the process of brick confection: In the first step, the brick mixture was introduced into a sample holder and then pressed with a pressure of $2.5 \mathrm{MPa}$ (Fig. 1a). After pressing, the excess material was removed, and the brick was finally removed from the sample holder (Fig. 1b). The bricks produced were introduced into a humidity chamber (EQUILAM, model SS600UMe) at a temperature of $23 \pm 2{ }^{\circ} \mathrm{C}$ and a relative humidity $\geq 95 \%$ in accordance with the standard procedure of confection and cure-cylinder bricks (NBR 12024/92) for 28 and $60 \mathrm{~d}$.

\subsection{Characterization of brick samples}

After the 28- and 60-day cure periods in the humidity chamber, the physical and mechanical properties of sample bricks, such as water-absorption values and compressive strength, were determined in accordance with the procedure of the NBR 8492/92 standard. For compressive strength, a press (TIME GROUP trademark model YAW-2000D) with a press strength of $500 \mathrm{~N}(50 \mathrm{kgf} / \mathrm{s})$ was used.

Solid-residue classification was performed with bricks of lime-residue-clay, which yielded better results in terms of physical and mechanical properties, in accordance with the NBR 10.004/04 standard. Both the leaching and solubilized extracts of solid residues were analysed in accordance with the ABNT NBR 10005/04 and NBR 10006/04 standards.

\section{Results}

\subsection{Characterization of raw materials}

Fig. 2 presents the size distributions of the raw materials used (clay, soapstone powder and $\mathrm{Fe}-\mathrm{Si}-\mathrm{Mn}$ slag). As can be observed by the size distribution, the soapstone powder $(\sim 50 \%-37 \mu \mathrm{m})$ was finer than the clay $(\sim 25 \%-37 \mu \mathrm{m})$ followed by the $\mathrm{Fe}-\mathrm{Si}-\mathrm{Mn}$ slag $(\sim 3 \%-37 \mu \mathrm{m})$.

Figs. 3-6 show the X-ray powder diffraction patterns of the clay, lime, soapstone powder and $\mathrm{Fe}-\mathrm{Si}-\mathrm{Mn}$ slag. The identified minerals in the clay sample were quartz $\left(\mathrm{SiO}_{2}\right)$, kaolinite $\left(\mathrm{SiO}_{2} \mathrm{~A}\right.$ $\left.\mathrm{l}_{2} \mathrm{O}_{5}(\mathrm{OH})_{4}\right)$ and muscovite $\left(\mathrm{KAl}_{2}\left(\mathrm{Si}_{3} \mathrm{Al}_{1}\right) \mathrm{O}_{10}(\mathrm{OH})_{2}\right)$. The lime sample contained the phases portlandite $\left(\mathrm{Ca}(\mathrm{OH})_{2}\right)$, calcite $\left(\mathrm{CaCO}_{3}\right)$ and nacrite $\left(\mathrm{Al}_{2} \mathrm{Si}_{2} \mathrm{O}_{5}(\mathrm{OH})_{4}\right)$. In the $\mathrm{Fe}-\mathrm{Si}-\mathrm{Mn}$ slag sample, only the enstantite phase $\left(\mathrm{Mg}_{2} \mathrm{Si}_{2} \mathrm{O}_{6}\right)$ was identified. The identified minerals in the soapstone sample were talc $\left(\mathrm{Mg}_{3} \mathrm{Si}_{4} \mathrm{O}_{10}(\mathrm{OH})_{2}\right)$ and chlorite $\left(\mathrm{H}_{16} \mathrm{Al}_{2.78} \mathrm{Fe}_{0.94} \mathrm{Mg}_{11.06} \mathrm{O}_{36} \mathrm{Si}_{5.22}\right)$, which is in accordance with Rodrigues and Lima (2012).

Table 2 depicts the physical properties of the raw material. The specific surface area of the clay sample was the highest, followed by the specific surface area of the lime sample. This result is likely related to the sample porosities and the presence of kaolinite in these samples (Figs. 3 and 4 ) as opposed to the size distribution (Fig. 2) since the soapstone powder was finer than other samples. The low humidity of soapstone compared with the other samples could be related to its natural hydrophobicity. The density of the materials varied from $2.45 \mathrm{~g} / \mathrm{cm}^{3}$ (lime) to $3.22 \mathrm{~g} / \mathrm{cm}^{3}$ (Fe-Si-Mn slag).

The chemical composition and loss on ignition (LOI) of the raw materials are presented in Table 3. The chemical composition of all analysed samples are in accordance with the main minerals identified in the diffraction patterns presented in Figs. 2 to 5. The higher LOI value of lime sample compared with the other raw samples is related to the carbonate (calcite) and hydroxide phases (portlandite and nacrite). 


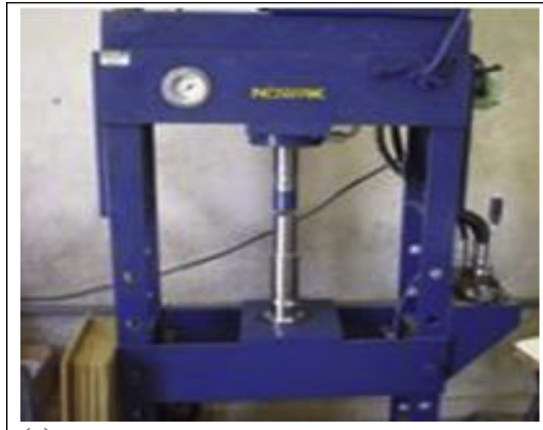

(a)

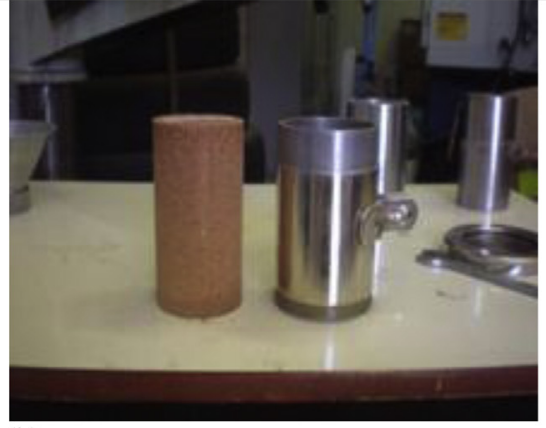

(b)

Fig. 1. Production of cylinder bricks: a) Material compaction by a hydraulic press at $2.5 \mathrm{MPa}$ and b) brick removal from the sample holder.

Table 4 compares the pozzolanic material's chemical specifications with the chemical compositions of wastes (soapstone powder and $\mathrm{Fe}-\mathrm{Si}-\mathrm{Mn}$ slag). Both of the analysed wastes have chemical compositions in accordance with E class pozzolanic materials (NBR 12653/92). Therefore, it is possible to replace part of the lime in the clay-lime brick mixture.

Atterberg indices: The liquidity limit and plasticity index of the clay samples were, respectively, $43.5 \%$ and $14.7 \%$. These values are in accordance with the specifications for clay-cement bricks (NBR

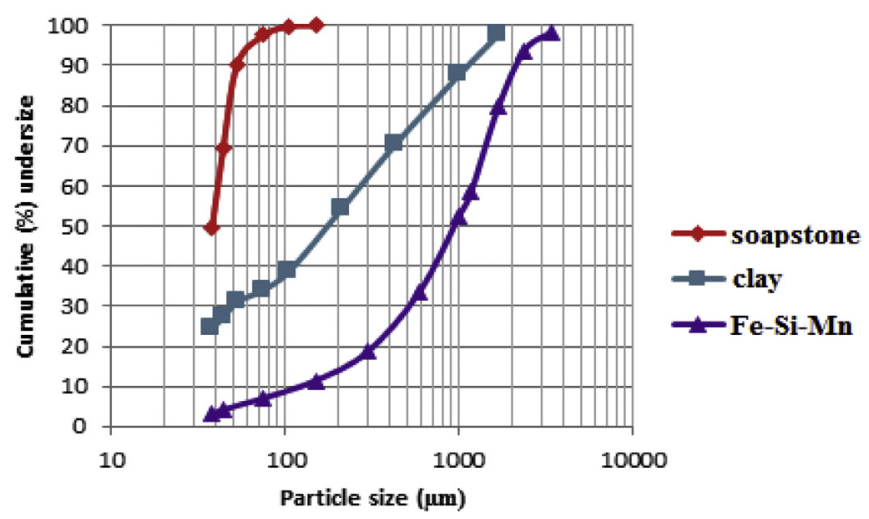

Fig. 2. Size distributions of raw materials.

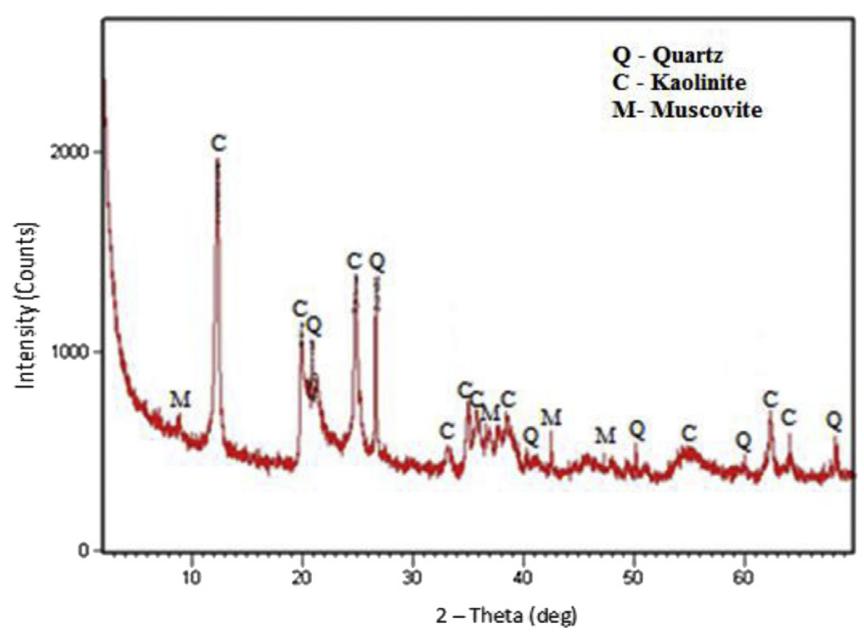

Fig. 3. X-ray powder diffraction pattern of the clay.
10832/89), which have limits on the maximum liquidity limit and plasticity index of $45 \%$ and $18 \%$, respectively. In accordance with The Unified Soil Classification System-USCS, this sample can be classified as ML (silt), which is described as inorganic silts and very-fine sand, rock alteration, fine silt or clay sand.

\subsection{Characterization of sample bricks}

Table 5 presents the water absorption of brick samples after 28 and 60 days of curing in the humidity chamber at the standard specification. The water absorption for all bricks was within the standard specification ( $\leq 20 \%$ ). As reported by Mahllawy (2008), the water absorption is related to the material resistance when the bricks are exposed to the environment.

Table 6 depicts the compressive strength of the produced bricks compared to the standard value (NBR 8492/84). In general, the compressive strengths of all clay-lime-soapstone bricks were higher than that of clay-lime-Fe-Si-Mn slag, which could be attributed to the finer size distribution (Fig. 2) and higher specific surface area of soapstone powder compared to $\mathrm{Fe}-\mathrm{Si}-\mathrm{Mn}$ slag (Table 2) because a higher contact area can increase the pozzolanic activity. The samples RF (clay-lime) and ST1 (25\% substitution of lime by soapstone powder) achieved compressive strengths within the standard value after a 28-day curing period. The sample bricks SL1 (25\% lime substitution by $\mathrm{Fe}-\mathrm{Si}-\mathrm{Mn}$ slag) demonstrated a compressive strength within the standard value after a 60-day

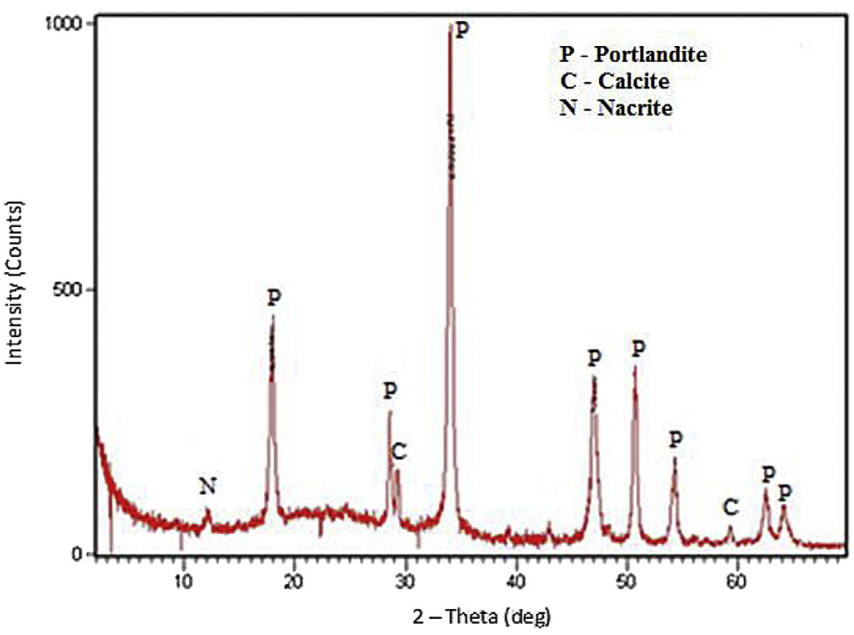

Fig. 4. X-ray powder diffraction pattern of the lime. 


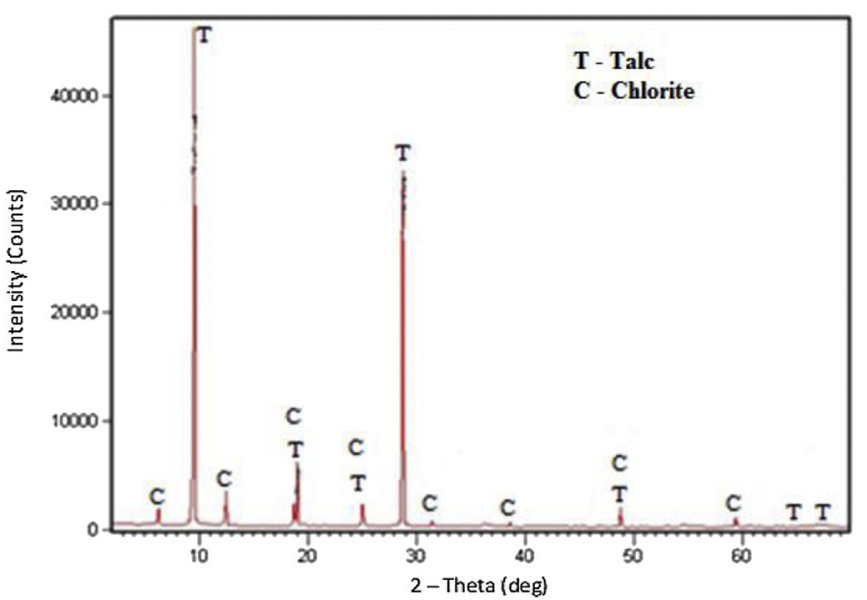

Fig. 5. X-ray powder diffraction pattern of the soapstone powder.

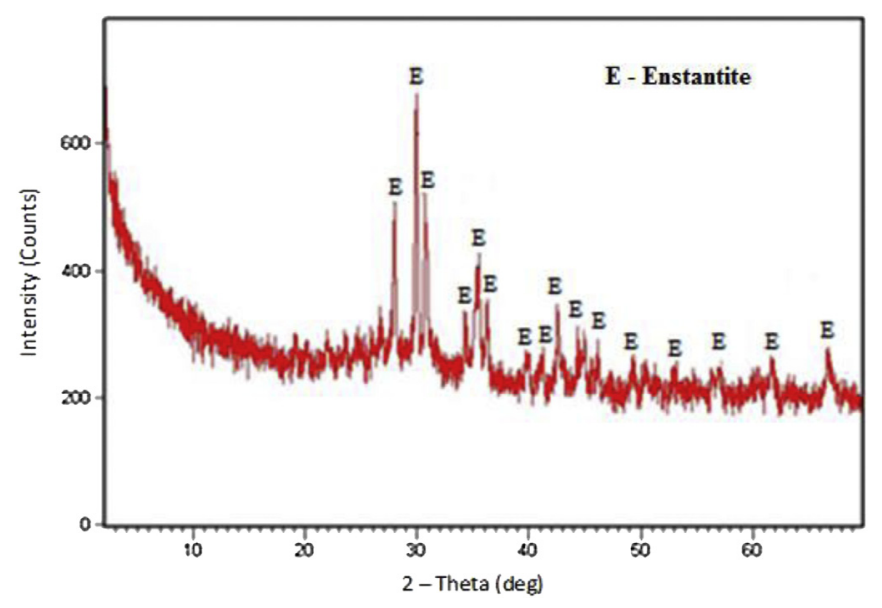

Fig. 6. X-ray powder diffraction pattern of the Fe-Si-Mn slag.

Table 2

Physical properties of the raw materials.

\begin{tabular}{|c|c|c|c|c|}
\hline Sample & $\begin{array}{l}\text { Specific surface } \\
\text { area }\left(\mathrm{m}^{2} / \mathrm{g}\right)\end{array}$ & Density $\left(\mathrm{g} / \mathrm{cm}^{3}\right)$ & Porosity (\%) & Humidity (\%) \\
\hline Clay & 32.414 & 2.593 & 1.6 & 12.530 \\
\hline Lime & 11.540 & 2.450 & 0.6 & 0.610 \\
\hline $\mathrm{Fe}-\mathrm{Si}-\mathrm{Mn}$ slag & 1.560 & 3.220 & 0.3 & 0.170 \\
\hline Soapstone powder & 3.430 & 2.960 & 0.2 & 0.340 \\
\hline
\end{tabular}

Table 3

Chemical composition and loss on ignition (LOI) of raw materials.

\begin{tabular}{|c|c|c|c|c|c|}
\hline \multicolumn{2}{|c|}{ Grade/compound } & \multirow{2}{*}{$\begin{array}{l}\text { Clay } \\
62.62\end{array}$} & \multirow{2}{*}{$\begin{array}{l}\text { Lime } \\
29.99\end{array}$} & \multirow{2}{*}{$\begin{array}{l}\text { Soapstone powder } \\
\text { (Rodrigues and Lima (2012) } \\
58.91\end{array}$} & \multirow{2}{*}{$\begin{array}{l}\text { Fe-Si-Mn slag } \\
36.57\end{array}$} \\
\hline Wt.\% & $\mathrm{SiO}_{2}$ & & & & \\
\hline & $\mathrm{MnO}$ & - & - & 0.04 & 21.72 \\
\hline & $\mathrm{Al}_{2} \mathrm{O}_{3}$ & 28.91 & 0.29 & 2.30 & 15.04 \\
\hline & $\mathrm{Fe}_{2} \mathrm{O}_{3}$ & 5.96 & 0.11 & 4.99 & 3.56 \\
\hline & $\mathrm{TiO}_{2}$ & 1.48 & - & - & - \\
\hline & $\mathrm{K}_{2} \mathrm{O}$ & 0.64 & - & - & 1.44 \\
\hline & $\mathrm{MgO}$ & 0.14 & 0.92 & 27.80 & 7.66 \\
\hline & $\mathrm{CaO}$ & & 67.21 & 0.07 & 11.33 \\
\hline & $\mathrm{SO}_{3}$ & - & - & 0.96 & 1.15 \\
\hline & LOI & 12.0 & 27.1 & 5.1 & - \\
\hline \multirow[t]{3}{*}{ ppm } & $\mathrm{Zn}$ & 36.70 & 7.61 & - & 10.96 \\
\hline & As & 5,38 & 5.56 & 3.32 & 9.75 \\
\hline & $\mathrm{Cu}$ & - & - & 16.93 & - \\
\hline
\end{tabular}

Table 4

The chemical specification of pozzolanic materials of E class (NBR 12653/92) compared with the chemical compositions of wastes (soapstone powder and $\mathrm{Fe}-\mathrm{Si}-\mathrm{Mn}$ slag).

\begin{tabular}{lllc}
\hline Chemical composition & $\begin{array}{l}\text { E class } \\
\text { (NBR 12653/92) }\end{array}$ & $\begin{array}{l}\text { Soapstone } \\
\text { powder }\end{array}$ & Fe-Si-Mn slag \\
\hline $\mathrm{SiO}_{2}+\mathrm{Al}_{2} \mathrm{O}_{3}+\mathrm{Fe}_{2} \mathrm{O}_{3}$, & 50 & 66.2 & 55.17 \\
$\quad$ minimum Wt.\% & & & \\
$\mathrm{SO}_{3}$, maximum Wt \% & 5.0 & 0.96 & 1.15 \\
$\mathrm{Humidity,} \mathrm{maximum} \mathrm{Wt.} \mathrm{\%}$ & 3.0 & 0.34 & 0.17 \\
LOI, maximum Wt.\% & 6.0 & 5.05 & - \\
$\begin{array}{l}\text { Free alkalis as } \mathrm{Na}_{2} \mathrm{O}, \\
\text { maximum Wt.\% }\end{array}$ & 1.5 & 0.03 & 0.74 \\
\hline
\end{tabular}

Table 5

Water absorption of sample bricks and standard deviation compared with the standard specification.

\begin{tabular}{lll}
\hline Sample brick & \multicolumn{2}{l}{ Water absorption (wt. \%) } \\
\cline { 2 - 3 } & $28 \mathrm{~d}$ & $60 \mathrm{~d}$ \\
\hline NBR 8492/84 standard & $\leq 20$ & $\leq 20$ \\
RF & $19.11 \pm 0.16$ & $19.25 \pm 0.11$ \\
ST1 & $19.01 \pm 0.37$ & $19.32 \pm 0.25$ \\
ST2 & $19.68 \pm 0.53$ & $19.37 \pm 0.18$ \\
ST3 & $19.77 \pm 0.52$ & $19.23 \pm 1.19$ \\
SL1 & $19.38 \pm 0.60$ & $19.17 \pm 1.65$ \\
SL2 & $19.68 \pm 0.48$ & $19.45 \pm 1.01$ \\
SL3 & $19.92 \pm 0.12$ & $19.52 \pm 0.94$ \\
\hline
\end{tabular}

Obs.: RF - reference; ST - soapstone; SL - slag.

curing period. However, as known, pozzolanic cementation is a slow and progressive process that can take months or years to complete. Thus, the compressive strength of the bricks will likely increase with the curing time for all samples.

Based on the results presented in Table 6 and on previous discussions, it is possible to conclude that the amount of $\mathrm{Ca}(\mathrm{OH})_{2}$ was sufficient for pozzolanic reaction only up to $25 \%$ lime replacement by both tested residues (soapstone or $\mathrm{Fe}-\mathrm{Si}-\mathrm{Mn}$ slag) because the obtained values of the evaluated parameters were similar to those measured in standard clay-lime $(10: 1)$ bricks.

The partial replacement of lime, which is most expensive component in the brick mixture, by soapstone powder and $\mathrm{Fe}-\mathrm{Si}-\mathrm{Mn}$ slag in clay-lime brick manufacturing could be useful in the Ouro Preto region because waste material is readily available and its use could decrease the final cost of the brick, providing both environmental and economic advantages.

Table 7 depicts the chemical composition of the brick leaching products, which possessed characteristics within the water absorption and compressive-strength standards (ST1 after 28- and 60 -day curing times and SL1 after a 60 day of curing). The elements

Table 6

Compressive strength of brick samples after 28- and 60-day cure periods and standard deviation compared with the standard specification.

\begin{tabular}{lll}
\hline Sample brick & \multicolumn{2}{l}{ Compressive strength (MPa) } \\
\cline { 2 - 3 } & $28 \mathrm{~d}$ & $60 \mathrm{~d}$ \\
\hline NBR $8492 / 84$ standard & $\geq 2.0$ & $\geq 2.0$ \\
RF & $2.10 \pm 0.00$ & $2.50 \pm 0.01$ \\
ST1 & $2.10 \pm 0.02$ & $2.20 \pm 0.03$ \\
ST2 & $1.94 \pm 0.01$ & $1.65 \pm 0.08$ \\
ST3 & $0.64 \pm 0.36$ & $1.10 \pm 0.01$ \\
SL1 & $1.73 \pm 0.11$ & $2.10 \pm 0.01$ \\
SL2 & $1.53 \pm 0.04$ & $1.30 \pm 0.01$ \\
SL3 & $0.63 \pm 0.01$ & $0.74 \pm 0.06$ \\
\hline
\end{tabular}


Table 7

Chemical composition of the brick leaching products.

\begin{tabular}{lccccc}
\hline Brick sample & \multicolumn{5}{l}{ Content of chemical elements $(\mathrm{mg} / \mathrm{L})$} \\
\cline { 2 - 6 } & As & $\mathrm{Ba}$ & $\mathrm{Cd}$ & $\mathrm{Cr}$ & $\mathrm{Pb}$ \\
\hline $\begin{array}{l}\text { Standard } \\
\quad \text { (maximum value) }\end{array}$ & 1.0 & 70.0 & 0.5 & 5.0 & 1.0 \\
$\quad$ (ABNT 10004/04) & & & & & \\
L28ST1 & $<0.004$ & 0.085 & $<0.009$ & 0.061 & $<0.026$ \\
L60ST1 & $<0.004$ & 0.093 & $<0.009$ & 0.058 & $<0.026$ \\
L60SL25 & $<0.004$ & 0.199 & $<0.009$ & 0.047 & $<0.026$ \\
\hline
\end{tabular}

Obs.: L28 - leaching product after $28 \mathrm{~d}$ cure time; L60 - leaching product after $60 \mathrm{~d}$ cure time; ST - soapstone; SL - slag.

Table 8

Chemical composition of the brick solubilised products.

\begin{tabular}{|c|c|c|c|c|}
\hline \multirow{2}{*}{$\begin{array}{l}\text { Chemical } \\
\text { element (mg/L) }\end{array}$} & \multicolumn{4}{|l|}{ Brick sample } \\
\hline & $\begin{array}{l}\text { Standard } \\
\text { (maximum value) } \\
(\text { ABNT } 10004 / 04)\end{array}$ & S28ST1 & S60ST1 & S60SL1 \\
\hline Al & 0.20 & 26.1 & 22.19 & 28.20 \\
\hline As & 0.01 & $<0.040$ & $<0.040$ & $<0.040$ \\
\hline Ba & 0.07 & $<0.001$ & $<0.001$ & $<0.001$ \\
\hline $\mathrm{Cd}$ & 0.005 & $<0.009$ & $<0.009$ & $<0.009$ \\
\hline $\mathrm{Cr}$ & 0.05 & 0.02 & 0.024 & 0.022 \\
\hline $\mathrm{Cu}$ & 2.0 & $<0.007$ & $<0.007$ & $<0.007$ \\
\hline $\mathrm{Fe}$ & 0.3 & 0.981 & 1.075 & 1.399 \\
\hline $\mathrm{Na}$ & 200.0 & 0.343 & 0.352 & 0.372 \\
\hline $\mathrm{Pb}$ & 0.001 & $<0.026$ & $<0.026$ & $<0.026$ \\
\hline $\mathrm{Zn}$ & 5.0 & $<0.003$ & $<0.003$ & $<0.003$ \\
\hline Mn & 0.01 & $<0.001$ & $<0.001$ & $<0.001$ \\
\hline
\end{tabular}

Obs.: S28 - solubilized product after 28 d cure time; S60 - solubilized product after 60d cure time; ST - soapstone; SL - slag.

$\mathrm{Hg}$, Se, $\mathrm{Ag}$ and fluoride were not analysed because these elements are not present in any brick mixture (Table 3). The chemical analysis, performed in accordance with the standard specification (Table 7), indicated that the sample brick residues can be classified as not-dangerous residues (residues of class II).

Table 8 presents the chemical compositions of the solubilised brick products. The compositions of the solubilised products were within the water absorption and compressive-strength standards (ST1 after 28- and 60-day curing times and SL1 after a 60 day of curing). Based on the chemical compositions presented in Table 8 , both wastes can be classified class II, non-inert residues.

Table 9 summarizes the qualification parameters given by the Brazilian Technical Standards for unfired clay-lime and the clay-soapstone or $\mathrm{Fe}-\mathrm{Si}-\mathrm{Mn}$ slag residues-lime bricks tested in this work. The results of using building waste as pozzolanic agents in soil-lime bricks (Patrício et al., 2013) and grit waste from the

Table 9

Comparison of unfired bricks produced in this study and by other researchers.

\begin{tabular}{|c|c|c|c|c|c|}
\hline Brick kinds & In this stud & & $\mathrm{RF}$ & $\begin{array}{l}\text { Patricio } \\
\text { et al. (2013) }\end{array}$ & $\begin{array}{l}\text { Siqueira and } \\
\text { Holanda (2013) }\end{array}$ \\
\hline $\begin{array}{l}\text { Composition } \\
\text { of brick }\end{array}$ & $\begin{array}{l}\text { Clay-lime- } \\
\text { soapstone }\end{array}$ & $\begin{array}{l}\text { Clay-lime- } \\
\text { Fe-Si-Mn } \\
\text { slag }\end{array}$ & $\begin{array}{l}\text { Clay- } \\
\text { lime }\end{array}$ & $\begin{array}{l}\text { Soil-lime- } \\
\text { building } \\
\text { waste }\end{array}$ & $\begin{array}{l}\text { Soil-cement- } \\
\text { grits waste }\end{array}$ \\
\hline $\begin{array}{l}\text { Compressive } \\
\text { strength (MPa) }\end{array}$ & 2.20 & 2.10 & 2.50 & 2.26 & 5.55 \\
\hline $\begin{array}{l}\text { Water } \\
\text { absorption (\%) }\end{array}$ & 19.35 & 19.17 & 19.5 & 13.5 & 17.5 \\
\hline Cure (d) & 60 & 60 & 60 & 90 & 28 \\
\hline $\begin{array}{l}\text { \% weight } \\
\text { replaced } \\
\text { by waste }\end{array}$ & 25 & 25 & 0 & 25 & 20 \\
\hline
\end{tabular}

cellulose industry as a partial replacement of Portland cement in soil-Portland cement bricks (Siqueira and Holanda, 2013) are also presented.

As can be observed in Table 9, the compressive strengths of the bricks incorporating both studied wastes in this work were similar to that of demolition waste bricks for the same weight \% of lime replaced by waste ( 25 wt.\%). The water absorption values determined in this study were higher than the demolition waste brick. However, the curing time of the bricks manufactured with demolition waste was $50 \%$ higher than that of the bricks with soapstone powder and $\mathrm{Fe}-\mathrm{Si}-\mathrm{Mn}$ slag. The smaller compressive strengths and higher water absorptions of the studied waste bricks in this work compared to bricks of soil-Portland cement-waste grit may be explained by the use of cement and the smaller proportion (20 wt.\%) of grit waste in this brick mixture despite the shorter curing time (28 d).

Based on current prices of Portland cement, lime, transportation and energy in Minas Gerais, Brazil, the cost to prepare one tonne of unfired brick mixture of soil-Portland cement and soil-lime (10:1), 25 wt.\% replacement of lime by soapstone powder or $\mathrm{Fe}-\mathrm{Si}-\mathrm{Mn}$ are of $\$ 39.11$ USD $\$ 33.33$ and $\$ 25.33$, respectively. This means that the cost of soil-lime and soil-studied wastes-lime mixtures are $17 \%$ and $32 \%$ lower compared with the soil-cement mixture, and the cost of the soil-studied wastes-lime mixture is $25 \%$ lower than the soil-lime mixture.

\section{Conclusions}

Based on this investigation of soapstone powder and $\mathrm{Fe}-\mathrm{Si}-\mathrm{Mn}$ slag, it was concluded that both wastes have chemical compositions useful for pozzolanic activities. The pressure strength of the bricks' clay-lime-residue (10:0.75:0.25) after 28- and 60-day cure times were within standard specifications $(>2.0 \mathrm{MPa})$ for soapstone powder. For $\mathrm{Fe}-\mathrm{Si}-\mathrm{Mn}$ slag, this specification was achieved only after a 60 day of curing. In accordance with the leaching and solubilised products from sample bricks, which achieved pressure strength within the standard specification $(\geq 2.0 \mathrm{MPa})$, both residues can be classified as class II residues, not inert.

\section{Acknowledgements}

Financial support by the CNPq, FAPEMIG, PROPP/UFOP and CAPES is gratefully acknowledged.

\section{References}

ABNT NBR 10004/04, 2004. Solid Waste - Classification. Brazilian Association of Technical Standards, Brazil (in Portuguese).

ABNT NBR 10005/04, 2004. Procedure for Obtainment Leaching Extract of Solid Wastes. Brazilian Association of Technical Standards, Brazil (in Portuguese).

ABNT NBR 10006/04, 2004. Procedure for Obtainment of Solubilized Extraction of Solid Wastes. Brazilian Association of Technical Standards, Brazil (in Portuguese).

ABNT NBR 10832/89, 1989. Manufacture of Solid Brick and Hollow Block of Soilcement with Use of Hydraulic Press. Brazilian Association of Technical Standards, Brazil (in Portuguese).

ABNT NBR 12024/92, 1992. Soil-cement - Confection and Cure-cylinder Bricks. Brazilian Association of Technical Standards, Brazil (in Portuguese).

ABNT NBR 12653/92, 1992. Pozzolanic Materials. Brazilian Association of Technical Standards, Brazil (in Portuguese).

ABNT NBR 6457/86, 1986. Soil Samples - Preparation for Compaction Tests and Characterization Tests. Brazilian Association of Technical Standards, Brazil (in Portuguese).

ABNT NBR 6459/84, 1984. Soil - Determination of Liquidity Limit. Brazilian Association of Technical Standards, Brazil (in Portuguese).

ABNT NBR 7180/84, 1984. Solo - Determination of Plasticity Limit. Brazilian Association of Technical Standards, Brazil (in Portuguese).

ABNT NBR 7182/86, 1986. Soil - Compaction Test. Brazilian Association of Technical Standards, Brazil (in Portuguese). 
ABNT NBR 8492/84, 1984. Soil-cement Bricks - Determination of Compressive Strength and Water Absorption, 1984. Brazilian Association of Technical Standards, Brazil, p. 5 (in Portuguese).

Figueiredo, S.S., 2011. Study of the Durability of Soil-lime Bricks Embedded with Demolition Construction Residues. Master dissertation. Graduation Program in Civil and Environmental Engineering, Federal University of Campina Grande, Paraíba, Brazil, p. 107 (in Portuguese).

Gencel, O., Ozel, C., Koksal, F., Erdogmus, E., Martínez-Barrera, g., Brostow, W., 2012. Proprieties of concrete paving blocks made with waste marble. J. Clean. Prod. $21,62-70$.

Gencel, O., Sutcu, M., Erdogmus, E., Koc, V., Cay, V.V., Gok, M.S., 2013. Proprieties of bricks with waste ferrochromium slag and zeolite. J. Clean. Prod. 59, 111-119.

IBRAM Brazilian Mining Institute, 2012. Mineral Economy. ibram.org.br (accessed 05.06.14.) (in Portuguese).

Jesus, C.A.G., 2012. Mineral Summary 2012. National Department of Mineral Production. dnpm.gov.br (accessed 05.06.14.) (in Portuguese).

Mahllawy, M.S., 2008. Characteristics of acid resisting bricks made from quarry residues and waste steel slag. Constr. Build. Mater. 22, 1887-1896.
Marino, L.F.B., Boschi, A.O., 1998. The Thermal expansion of ceramic materials part 1: introduction, applications and mass composition. Ind. Ceram. 3, 17-21 (in Portuguese).

Nascimento, K.A.L., 2007. Use of Slag from the Recycling of Steel in Concrete Port land Cement. Master dissertation. Graduation in Materials Engineering, University of São Paulo, São Paulo, Brazil, p. 128 (in Portuguese).

Olsen, S.E., Tangstad, M., Lindstad, T., 2007. Production of Manganese Ferroalloys. Tapir academic Press, Trondheim, Norway, p. 247.

Patrício, S.M.R., Figueiredo, S.S., Bezerra, I.M.T., Neves, G.A., Ferreira, H.C., 2013. Soillime bricks using building waste. Ceramics 59 (349), 27-33 (in Portuguese).

Pelisser, F., Zavarise, N., Longo, T.A., Bernardin, A.M., 2011. Concrete made paving with recycled tire rubber: effect of alkaline activation and silica fume addition. J. Clean. Prod. 19, 757-763.

Rodrigues, M.L.M., Lima, R.M.F., 2012. Cleaner production of soapstone in the Ouro Preto region of Brazil: a case study. J. Clean. Prod. 32, 149-156.

Siqueira, F.B., Holanda, J.N.F., 2013. Reuse of grits waste for the production of soilcement bricks. J. Environ. Manag 131, 1-6.

WSA. World Steel Association. worldsteel.org. (accessed 05.06.13.). 